\title{
Kirigala forest fragments and the identity as a dipterocarp plantation or Hora Kele of Ingiriya
}

\author{
I.A.D.N. Dilrukshi and S.M.W. Ranwala* \\ Department of Plant Sciences, Faculty of Science, University of Colombo, Colombo 03.
}

Revised: 30 December 2015; Accepted: 21 January 2016

\begin{abstract}
Fragmentation has exposed the Kirigala forest to the influence of various neighbourhood land-use practices. The present study investigated the floristic, soil and micro-climatic conditions of the forest and demonstrated its degradation due to influences by human induced disturbances. Ten $50 \mathrm{~m}$ $\times 5 \mathrm{~m}$ gradsects each accommodating 3 pairs of $10 \mathrm{~m} \times 5 \mathrm{~m}$ plots, a total of 60 soil samples and 20 seed traps provided floristic details, seedling emergence from seed bank and annual seed rain of the forest, respectively. Diversity of the edge and the forest interior were compared for the different neighbourhood land use types using the Shannon and Weiner (H) and Simpsons reciprocal (D) indices. Change in the forest structure was illustrated using profile diagrams. Differences in soil $\mathrm{pH}$, soil moisture, nitrogen, available phosphorous and potassium, organic matter content, air temperature, humidity and light intensity between the forest edge and the interior were determined. Soil, microclimate and species richness were combined for clustering of similar areas. The site reported the presence of 55 tree, 12 shrub, 15 herb, 07 climber and 02 vine species including a total of 23 endemic species and 06 invasive species. A higher diversity was observed at the edge, and the highest was observed beside roads as indicated by both diversity indices $\mathrm{H}$ and $\mathrm{D}$. Soil and microclimate of the forest varied significantly between the edge and the interior and reflected anthropogenic influences and neighbourhood land use practices. Dominance hierarchy of the trees was Dipterocarpus zeylanicus $>$ Gaertnera vaginans $>$ Aporusa lanceolata, while that for undergrowth/shrubs herbaceous species was Ochlandra stridula $>$ Dracaena thwaitesii $>$ Piper sylvestre. Annual seed rain contained propagules of 23 plant species, while invasive Alstonia macrophylla provided the highest density of seeds. Establishment of foot paths, selective removal of juveniles by root-balling technique and encroachment for crop cultivation have also facilitated the degradation process. It is vital to pay attention on maintaining the ecological stability of this forest before it loses its identity as the Hora Kele of Ingiriya.
\end{abstract}

Keywords: Edge effect, forest fragmentation, Hora Kele, Ingiriya, Kirigala.

\section{INTRODUCTION}

Forest fragmentation is considered as a major threat that challenges the conservation of biodiversity (Collinge, 1996; Echeverria et al., 2006; Dixo et al., 2009; Tawatao et al., 2011). It creates an abrupt transition between ecosystems and exposes closed forest habitats to neighbourhood land uses directly affecting forest resources and its services (Murcia, 1995; Broadbent et al., 2008; Pokhriyal et al., 2010; Porensky \& Young, 2013). Open areas with less biomass and structural complexity such as roads, barren areas and reservoirs commonly found around fragmented forests extend the 'edge effect' towards the forest interior in comparison to structurally complex, closed edges with high biomass (Marchand \& Houls, 2005; Lin \& Cao, 2009). The edge effect creates gradients of light, temperature, moisture, and wind speed between the forest exterior and interior (Collinge, 1996; Broadbent et al., 2008) facilitating the access of various organisms and materials (pollutants, seeds, pollen) into the forest. As a result, cascades of responses can be observed including changes in forest structure, canopy cover, species composition, tree mortality, seed bank and seed rain affecting the ecological stability of the forest (Murcia, 1995; Gordefroid \& Koedam, 2003; Harper et al., 2005).

At present forest ecosystems in many suburban areas of the South West of Sri Lanka are found in small isolated patches compared to the few large continuous patches located in the wilderness. Due to population pressure and continuous urban expansion, survival of these small forest fragments have been highly threatened (MoFE, 1999; MoENR, 2009; IUCN-MoESE, 2012). Especially 
those located in the suburban areas are subjected to frequent human interventions and trade offs during urban and industrial expansion. Their role in carbon sequestration, microclimate regulation, noise reduction, air purification, recreation, and cultural values have been overlooked in many instances. For the sustainable development of cities, it is of vital importance to restore and conserve forest habitats along a suburban gradient to ameliorate the negative effects reflected from the urban core environment. Moreover maintenance of habitat connectivity of forest habitats is equally important for the maintenance of species diversity and their interactions (Collinge, 1996; Tawatao et al., 2011).

Kirigala forest is among the few forest patches located in the suburban area of Colombo. According to Oudshoorn (1961), Kirigala had been a degraded forest and saplings of Dipterocarpus zeylanicus Thw. (herein referred to D. zeylanicus) and Artocarpus heterophyllus Lam. were introduced by the Forest Department in 1940 to increase the canopy cover and timber potential. Hence, it was commonly known as 'Dipterocarp plantationHora Kele' despite a very few other native forest species growing in association. For the last 70 years, Kirigala has also been serving as a repository for propagules of rainforest species that have been brought to the site by wind and animals. Establishment of asphalt roads across the forest as a consequence of urbanisation not only fragmented it into three segments but also assisted intermittent logging, clearing of undergrowth and establishment of footpaths across the forest (personal communication with elderly villagers, June 2013). Following the declaration of Kirigala as a proposed forest reserve in 1980, impacts of such activities were expected to minimise. However, Kirigala is still being exposed to various influences from neighbourhood landuse practices and illegal anthropogenic activities that facilitated its degradation and threatens its survival. Hence an in-depth study of its current ecological status is of vital importance for forest managers to identify the most appropriate restoration practices in order to maximise the forest ecosystem services.

This study determined the floristic, micro-climatic and, soil parameters at the edge and the interior of Kirigala forest using qualitative and quantitative methods to elicit degradation status of the forest due to edge effect and other influences by the neighbourhood land-use practices.

\section{METHODOLOGY}

\section{Study site}

The study was conducted at the Kirigala forest of Ingiriya $\left(6.780215^{\circ} \mathrm{N}, 80.14906^{\circ} \mathrm{E}, 50 \mathrm{msl}, 16 \mathrm{ha}\right)$ located in the Kalutara District of the Western Province (Figure 1), which receives an average annual rainfall $>2500 \mathrm{~mm}$ and the highest monthly rainfall of $1500-2000 \mathrm{~mm}$ during May-September while maintaining an average annual temperature of $28^{\circ} \mathrm{C}$ (FCRDC, 2013).

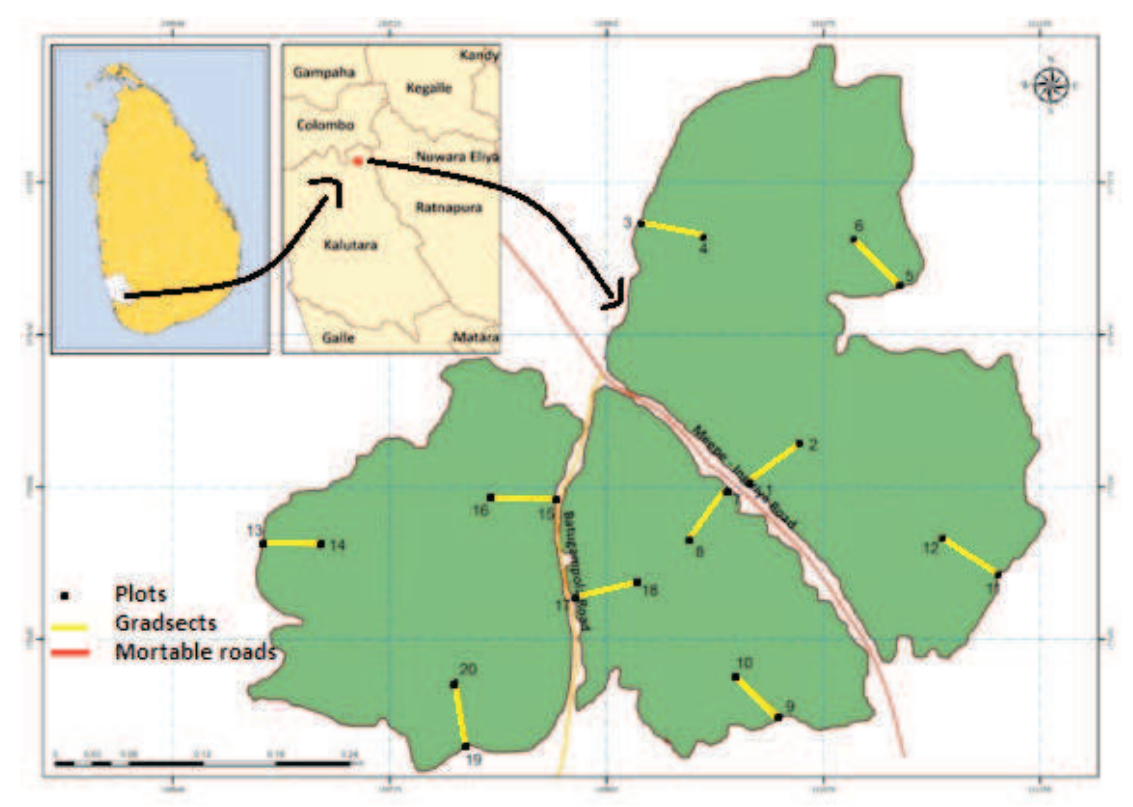

Figure 1: Location of the study area and placement of gradsects. Odd numbers represent plots at edge, while even numbers represent interior plots. 


\section{Floristic diversity}

Following a preliminary survey, neighbourhood land-use types were identified and representative sampling areas were chosen. Vegetation samples included ten $50 \mathrm{~m} \times 5 \mathrm{~m}$ gradient directed transects (grad-sects), each containing 3 pairs of $10 \mathrm{~m} \times 5 \mathrm{~m}$ plots placed at $0-10 \mathrm{~m}$ (herein referred as edge plots), $20-30 \mathrm{~m}$ and $40-50 \mathrm{~m}$ (herein referred as interior plots) from the forest edge towards the interior. In each plot, species composition of seedlings $(<1 \mathrm{~m}$ height), juveniles $(>1 \mathrm{~m}$ height and $\mathrm{dbh}<5 \mathrm{~cm}$ ) and trees $(\mathrm{dbh}>5 \mathrm{~cm})$ were identified using available literature (Dasanayake et al., 1995-2006; Senaratne, 2001; de Vlas, 2008) and individuals were counted. Forest undergrowth was enumerated using the BraunBlanquet cover abundance scale in two $1 \mathrm{~m} \times 1 \mathrm{~m} \mathrm{sub}$ plots per plot. Important value and rank abundance curves were developed for trees, through which the dominance hierarchy of climax and colonising rainforest species and their families were identified. Important value index (IVI) was calculated using IVI $=\mathrm{RF}+\mathrm{RD}+\mathrm{RC}$ where, relative frequency $(\mathrm{RF})=$ frequency of one species $/$ total frequency of each species $\times 100$, relative density $(\mathrm{RD})=$ density of one species / total density of all species $\times 100$ and relative basal cover $(\mathrm{RC})=$ basal cover for one species / total basal cover of all the species $\times 100$ (Krebs, 2005). Age structure analysis of the three most important woody species were constructed, while analysis of variance (ANOVA) was carried out using Minitab version 16.1 .0 to identify the significant variation among the abundance of seedlings, juveniles and adult trees in the edge ( $0-10 \mathrm{~m}$ away from boundary), and interior (40 $-50 \mathrm{~m}$ away from boundary) of the forest. In order to calculate the IVI for herbaceous species, density was considered as the sum of the Braun Blanquet scores / total number of quadrats, while frequency was calculated as the percentage occurrence of species (Stern et al., 2004; Krebs, 2005). Profile diagrams were drawn for three grad-sects that best illustrated the effect of each surrounding land-use type on the spatial distribution of plants from the forest edge to interior. Plants $<1 \mathrm{~m}$ height were not considered for such diagrams. Shannon Weiner $\left(\mathrm{H}=-\sum \mathrm{P}_{\mathrm{i}} \ln \mathrm{P}_{\mathrm{i}}\right)$ and Simpsons reciprocal indices $\left[\mathrm{D}=\mathrm{N}(\mathrm{N}-1) / \sum \mathrm{n}_{\mathrm{i}}\left(\mathrm{n}_{\mathrm{i}}-1\right)\right]$ were used to assess the species diversity between the edge and the interior of the forest and among neighbourhood land-use types (Stern et al., 2004). During the study human interventions to the forest were also recorded.

\section{Soil and micro-environment}

Air and soil temperature, light intensity and humidity were measured in plots at the edge and the interior using mercury thermometer, lux meter (KIMO-2000) and hygrometer (Elitech DT-3), respectively on monthly basis. Twelve composite soil samples were obtained from top soil at a depth up to $10 \mathrm{~cm}$ using the soil corer from the edge and the interior plots of six grad-sects. Soil pH (using $\mathrm{pH}$ meter MARTINI $\mathrm{pH}$ 55), soil moisture content (oven-drying method), and soil organic matter content (dry combustion method) were determined (Ghimire et al., 2007). Total nitrogen was determined through the Kjeldhal method and the available nitrate content in each sample of soil was calculated using a spectrophotometric method. Soil potassium content was measured using the flame photometer and phosphorous was determined by modified Murphy and Riley method (Olsen, 1954). Statistical $\mathrm{T}$ tests were performed separately using Minitab version 16.1.0 for chemical, physical and microclimatic data to compare the difference between the edge and interior of the forest.

Cluster analysis was conducted incorporating species richness, chemical, physical and microclimatic data at the edge and the interior of the forest using PAST ecological software version $2.17 \mathrm{~b}$ to quantify the similarity/dissimilarity of vegetation between the edge and the interior.

\section{Seed rain and seed bank of forest}

Seed rain was enumerated using twenty seed traps $(1 \mathrm{~m} \times 2 \mathrm{~m})$ made up of nylon mesh cloth, placed in adjoining plots of both the edge and the interior of the forest $1 \mathrm{~m}$ from the ground. Seeds from the traps were collected monthly for 12 months (August 2013 - July 2014), identified and categorised according to their dispersal mode: autochory, anemochory, epizoochory, endozoochory. The richness and abundance of seed rain was determined and the dispersal spectrum for the forest edge and interior was constructed.

From the plots located at the edge, middle and interior of each grad-sect, top soil $(0-10 \mathrm{~cm})$ was taken using a soil corer to determine the soil seed bank using germination technique. The soil obtained from the plots was placed separately in trays lined with filter paper. Sixty trays were kept moist in the forest neighbourhood environment to receive the same micro-environmental conditions and the emerging seedlings were recorded for six months on weekly basis. As a control, composite samples from the edge mid and forest interior were oven-dried at $105{ }^{\circ} \mathrm{C}$ for $24 \mathrm{hrs}$ and placed on 5 trays prepared as above. Emerging seedlings were identified and categorised into woody plants, vines and climbers, and herbs to determine their differences in abundance among the edge, middle and the interior of the forest. Analysis of variance (ANOVA) was carried out using Minitab version 16.1.0. 


\section{RESULTS}

\section{Neighbourhood land-use types of the forest}

The neighbourhood land-use types included roads and croplands in which paddy, rubber, pineapple, coffee and tea were grown in small scale. Built-up areas consisted of a textile factory, school and homesteads.

\section{Floristic differences between forest edge and interior}

The species richness of Kirigala forest recorded 91 plant species belonging to 74 genera and 39 families. This included 55 tree species, 12 shrub and 15 herbaceous species, 07 climber species and 02 vine species. The flora also accommodated 23 endemic species and 06 invasive alien species of national importance. From the forest edge, 70 plant species belonging to 35 families were reported compared to the 41 plant species belonging to 28 families recorded at the interior (Appendix). The common plant families of the forest were Euphorbiaceae, Moraceae, Anarcardaceae, Apocynaceae, Dilleniaceae and Rubiaceae. The plant families that accommodated successional and/or colonising species contributed more towards the species richness of the Kirigala forest compared to the common plant families of climax lowland rainforests such as Dipterocarpaceae, Rhizophoraceae, Symplocaceae, Thymelaceae, and Vitaceae which exhibited a low contribution.

As reflected by the IVI of all tree species found in the forest, the three most dominant tree species of Kirigala forest were D. zeylanicus, Gaertnera vaginans (DC.) Merr. and Aporusa lanceolata (Tul.) Thw., respectively. The same order of dominance was reported from the interior plots while at the forest edge the position of the third most dominant species was occupied by Fahrenheitia minor (Thw). Among the undergrowth herbaceous species of the forest, Ochlandra stridula Moon ex Thw., Dracaena thwaitesii Regel, and Piper sylvestre Lam. were placed along the dominance hierarchy.

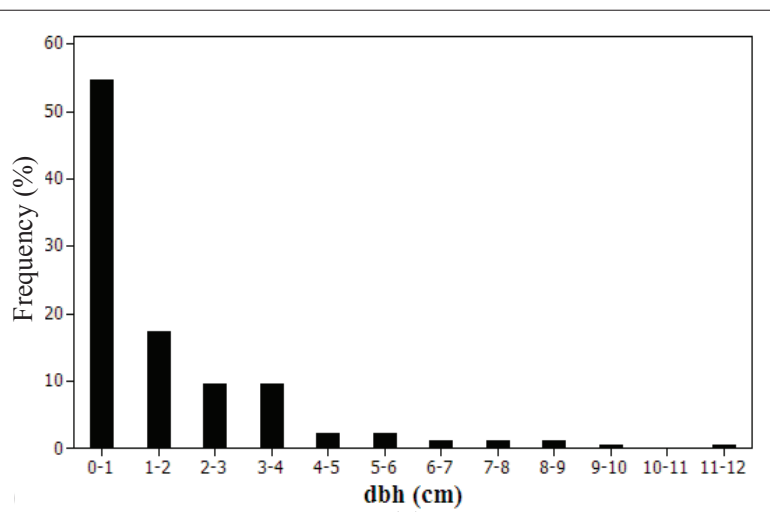

(a)

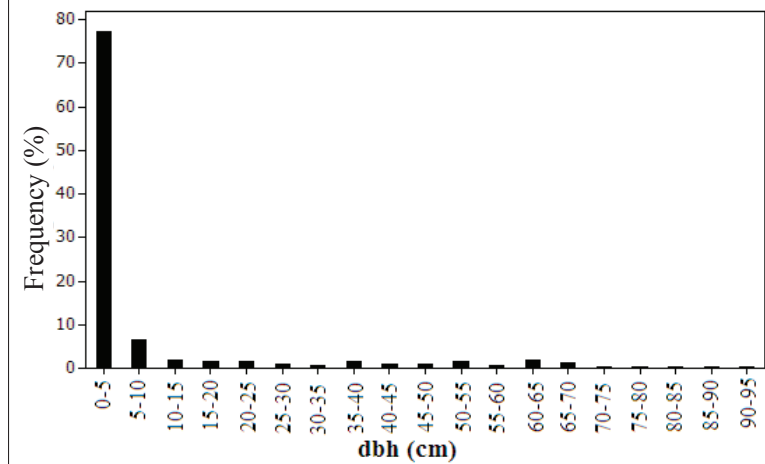

(b)

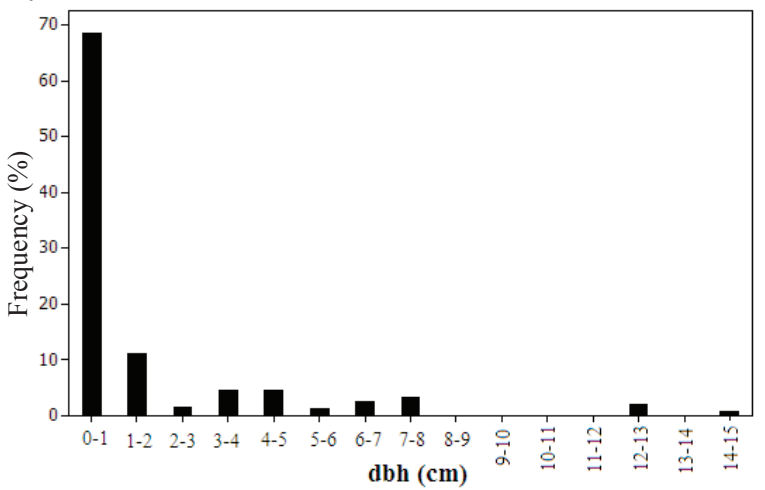

(c)

Figure 2: Age structure distribution of the three most important woody species in Kirigala forest (a) D. zeylanicus; (b) A. lanceolata and (c) G. vaginans

Table 1: Species diversity at the edge and the interior of the forest with respect to different land use types

\begin{tabular}{lcccccccc}
\hline Land use & \multicolumn{7}{c}{ Species diversity } \\
type & Overall & Roads & Croplands & $\begin{array}{c}\text { Built-up } \\
\text { areas }\end{array}$ & Overall & Roads & Croplands & $\begin{array}{c}\text { Built-up } \\
\text { areas }\end{array}$ \\
\hline \multirow{2}{*}{$\begin{array}{l}\text { Edge } \\
\text { Interior }\end{array}$} & 3.10 & 3.06 & 2.55 & 2.63 & 14.01 & 14.10 & 6.16 & 9.71 \\
\hline
\end{tabular}


Age structure analysis significantly reflected the high abundance $[\mathrm{p}(0.000)<0.05]$ of seedlings and juveniles of D. zeylanicus, A. lanceolata, and $G$. vaginans than that of adult trees (Figure $2 \mathrm{a}, \mathrm{b}, \mathrm{c}$ ). The Shannon Weiner and Simpsons reciprocal indices provided evidence for high floristic diversity at the edge compared to the forest interior and its variation according to the neighbourhood land-use types (Table 1). As the Shannon index emphasises the species richness whilst the Simpsons reciprocal index emphasises the unevenness component of diversity (Nagendra, 2002), it was clearly shown that the type of land-uses of the surroundings also had an impact on the floristic diversity of the forest edge. Thus the vegetation of forest edges bordering roads and builtup areas were more diverse and uneven than that of the forest edge bordering croplands.

The forest canopy of Kirigala estimated at $50 \mathrm{~m}$ height was discontinuous, scanty and mainly composed of D. zeylanicus, Alstonia macrophylla Wall. Ex G. Don and Artocarpus heterophyllus. Forest canopy adjacent to the croplands consisted mainly of D. zeylanicus and Artocarpus nobilis Thw. More or less equalsized juveniles of the canopy species occupied the sub canopy a bit further (about $10 \mathrm{~m}$ ) from the edge (Figure 3a). Canopy of the forest bordering built-up area was relatively dense but consisted only of $D$. zeylanicus. The sub canopy layer was abundant near the edge and consisted of D. zeylanicus, Bridelia retusa (L.) A. Juss. and Melicope lunu-ankenda (Gaertn.) T. Hartley (Figure 3b). Canopy of the forest areas bordering roads was dominated by $D$. zeylanicus and the sub canopy was not at all visible near the forest edge. Trees such as $B$. retusa and Chaetocarpus coriaceus Thw. were found to occupy the sub canopy layer about $30 \mathrm{~m}$ towards the interior from the forest edge (Figure 3c).

The composition of the under-story of the forest primarily comprised Aporusa lanceolata, Gaertnera vaginans, Mallotus rhamnifolius (Willd.) Muell. Arg. and Fahrenheitia minor. The ground layer was composed of Adinatum spp., Christella spp., Dracaena thwaitesii and Ochlandra stridula. A comparatively dense undergrowth was reported from the forest areas bordering roads and built-up areas, while the forest undergrowth near the croplands was cleared and consisted mainly of coffee and rubber saplings. It was noticed that built up areas and roads had always provided access to the forest via footpaths that disturbed the undergrowth due to trampling. This could have suppressed the seedling establishment of woody forest species simultaneously increasing the density of disturbance-preferred herbaceous pioneer species.
Soil and microclimatic changes between edge and interior

Soil moisture and humidity contents were higher in the forest interior than at the forest edge. In contrast, air temperature and light intensity were reported high at the forest edge (Table 2). Although soil $\mathrm{pH}$ and organic matter content were found to be more or less similar at the forest edge and the interior, variation of nitrogen, potassium and phosphorous contents of soil reflected possible impacts from the neighbourhood land-use types on the forest. Total and available soil nitrogen contents assessed using the Kjeldhal and spectrophotometric methods did not show detectable amounts of nitrogen except in samples of the forest edge bordering the cropland. At this site a nitrate content of $1.12 \mu \mathrm{g} \mathrm{g}^{-1}$ was reported. The potassium content was higher at the edge $\left(5.47 \mu \mathrm{g} \mathrm{g}^{-1}\right)$ compared to the interior of the forest $\left(3.34 \mu \mathrm{g} \mathrm{g}^{-1}\right)$. High soil nutrient contents are often reported from open forest edges, but in this study the highest soil nutrients were reported only from samples of the forest edge bordering croplands. It may be a possible consequence of the use of agrochemicals by the crop growers.

The cluster analysis also clearly identified that there was a contrasting difference between the edge and the interior of Kirigala forest. Edge and interior plots were separated at $54 \%$ similarity exhibiting a contrasting difference (Figure 4). The next separation of sample plots was at $66 \%$, which isolated interior plot 12 and edge plot 1 from the rest of their respective groups. However, edge

Table 2: Micro-climatic parameters and soil nutrient content at forest edge and interior

\begin{tabular}{lcc}
\hline Soil micro-climatic parameters & Edge & Interior \\
\hline Soil moisture content $(\%)^{*}$ & 18.86 & 22.26 \\
Air temperature $\left({ }^{\circ} \mathrm{C}\right)^{*}$ & 30.16 & 29.14 \\
Soil temperature $\left({ }^{\circ} \mathrm{C}\right)^{*}$ & 28.95 & 27.74 \\
Light intensity $(\mathrm{Lux})^{*}$ & 1968.00 & 576.00 \\
Humidity $(\%)^{*}$ & 75.50 & 81.95 \\
Potassium $\left(\mu \mathrm{g} \mathrm{g}^{-1}\right)^{*}$ & 5.47 & 3.343 \\
Nitrogen $\left(\mu \mathrm{g} \mathrm{g}^{-1}\right)^{*}$ & 1.12 & Not \\
& as detected at & detectable \\
& edge bordering & \\
Phosphate $\left(\mu \mathrm{g} \mathrm{g}^{-1}\right)$ & croplands & \\
Organic matter content $(\%)$ & 0.078 & 0.081 \\
pH & 7.27 & 5.02 \\
\hline
\end{tabular}

The values are averages $(n=10$ for microclimatic parameters and $\mathrm{n}=6$ for soil nutrient contents).

*Significance is indicated at $\mathrm{p}(0.000)<0.05$ 

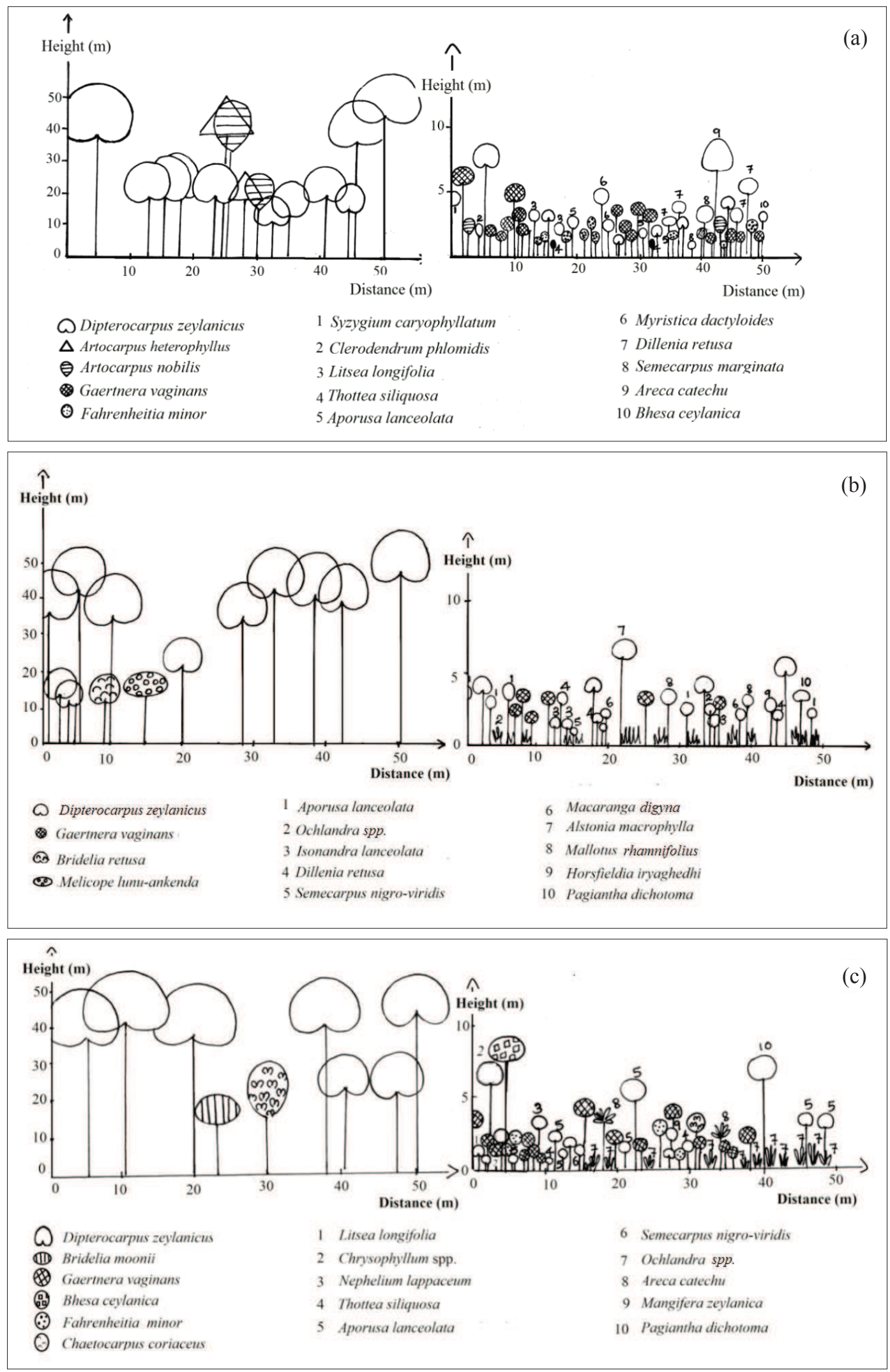

Figure 3: Profile diagrams of the Kirigala forest showing distribution of species with regard to neighbourhood land use types (a) cropland; (b) built-up area; (c) roads 


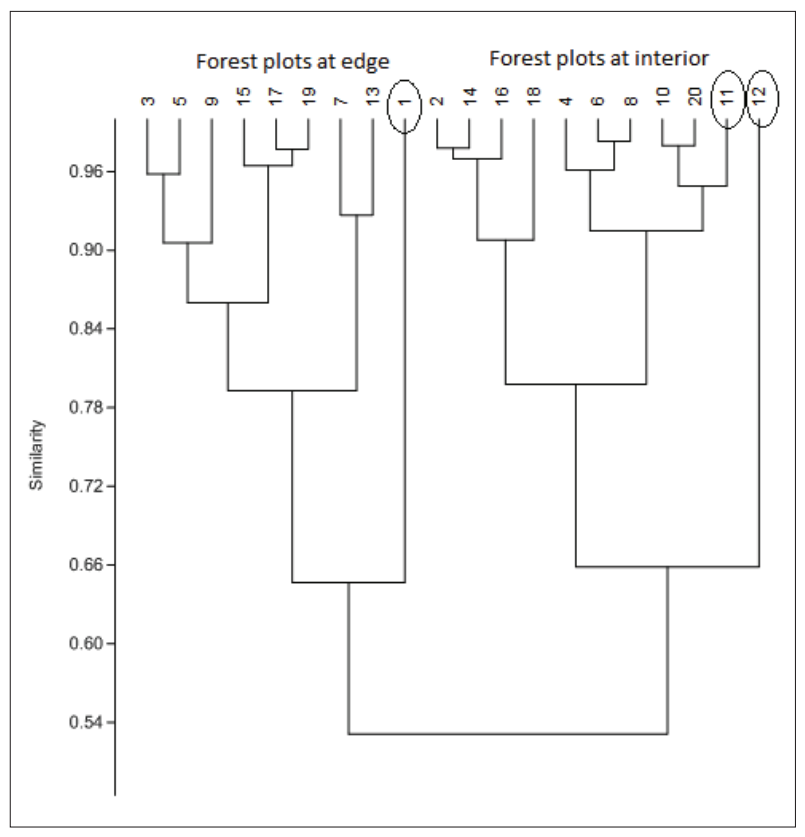

Figure 4: Dendrogram of plots resulted from cluster analysis that represented the chemical and physical parameters of soil and microclimatic data and species richness of forest edge and interior. Odd numbers represent edge plots and even numbers represent interior plots. plot 11 was merged with the interior group. The reasons for this separation was understood when the location of plots and their individual environmental data were compared. It was adjacent to a rubber land, hence low light intensity, mild wind speed and a cooler microhabitat has been reported from edge plot 11. Edge plot 1 was located adjacent to the road and showed the highest light intensity (3900 Lux), air and soil temperature; hence separated from its main cluster. With the dense canopy cover, interior plot 12 also showed a low light intensity (200 Lux) compared to that of other interior plots, hence separated from the cluster of interior plots.

\section{Seed rain and seedling recruitment at Kirigala rain forest}

A total of 1351 seeds belonging to 23 species were reported from a total area of $20 \mathrm{~m}^{2}$ of the Kirigala forest during a 12 month period. A more diverse and abundant seed rain was reported at the forest edge compared to the forest interior. The annul seed rain, 106 seeds per $\mathrm{m}^{2}$ at the forest edge represented 21 plant species, while that of the forest interior was 34 seeds per $\mathrm{m}^{2}$ with the representation of only 9 plant species. Seeds found at the forest edge and interior varied significantly based upon seed dispersal modes: anemochory, autochory,

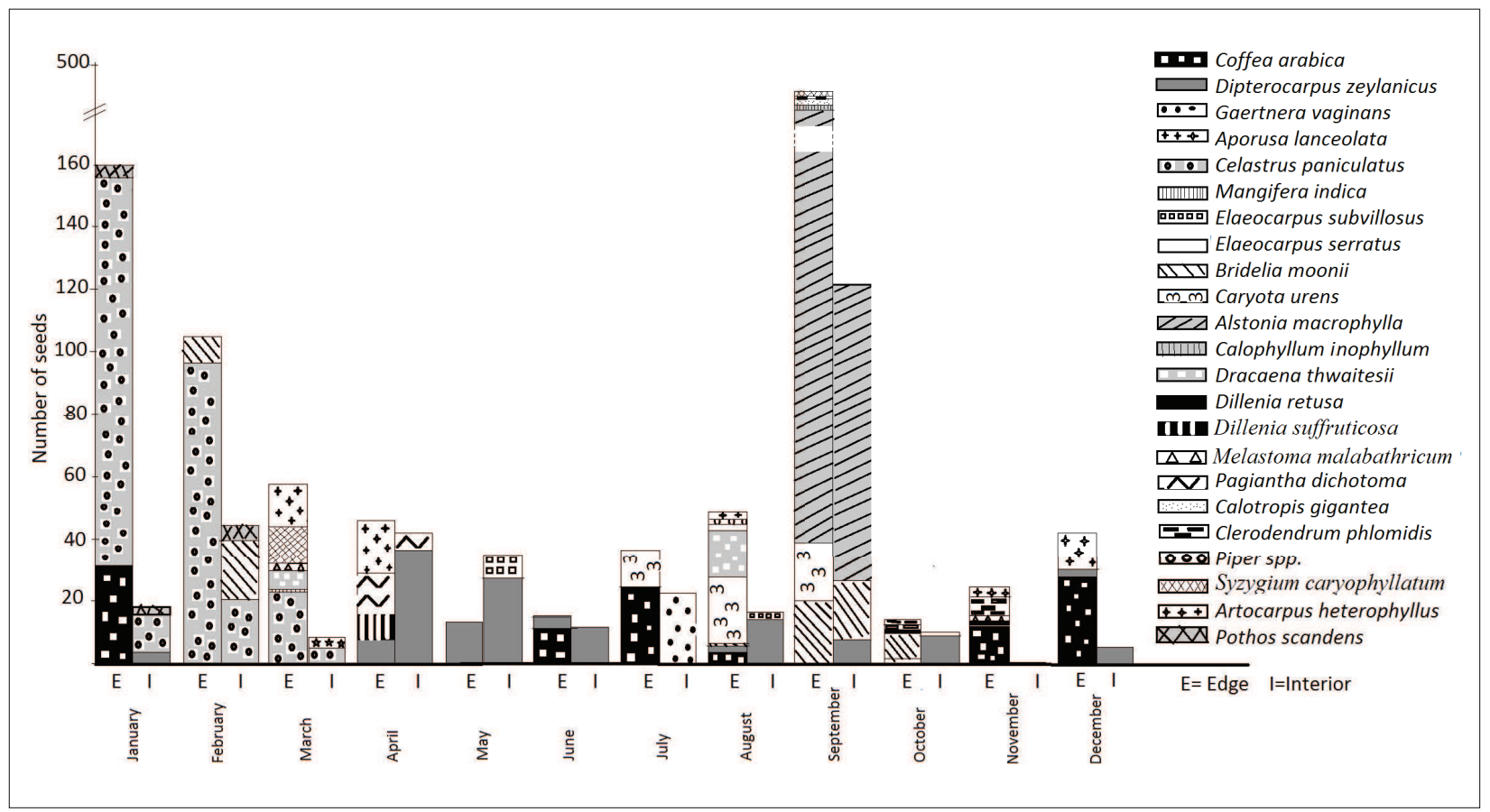

Figure 5: Seed dispersal spectrum of forest edge and interior at Kirigala Forest 
and epizoochory. Percentage representation of these categories at the forest edge were 23, 29 and $49 \%$, respectively compared to the interior where it reported 40, 20 and $40 \%$, respectively. Seeds of the crop Coffea arabica L. and of woody forest invaders such as Alstonia macrophylla and Dillenia suffruticosa (Griffiith) Martelli were among the seeds deposited at the forest edge.

Seed dispersal spectrum (Figure 5) indicated the arrival of seeds at Kirigala forest throughout the study year. A high abundance of seed input was observed in January - February and September months due to the increased number of seeds of Celastrus paniculates and Alstonia macrophylla, respectively. The variety of seeds received by the forest was greater between March to September months. The change in abundance and variety of the seeds may have reflected the seasonal production of fruits and seeds in the forest and its surroundings. However, it is vital to note that the highest number of seeds deposited at Kirigala were from a noxious forest invader Alstonia macrophylla.

Seed bank analysis reported 308 individuals representing 26 plant species over a six month period. The abundance of seedling recruitment decreased along a gradient from the forest edge to interior; 19 species $(n=156)$ forest edge $>14$ species $(n=82)$ mid-range $>1$ species $(n=70)$ at forest interior. The highest frequencies of seedlings were reported from Cyperus rotundus and Trema orientalis (L.) Blume. A high frequency of Clidemia hirta (L.) D. Don seedlings was also observed from soil taken from the forest edge. Seedlings of three invasive alien species were identified from the seed bank. These included Alstonia macrophylla, Clidemia hirta and Mikania cordata (Burm.) Robinson. The emergence of woody native forest plants were not observed during the study period.

The seedling emergence pattern from soil was not uniform throughout the period. In the first two months, pioneer invader species such as Trema orientalis, Clerodendrum phlomidis L., Macaranga peltata (Roxb.) Muell. Rg., Alstonia macrophylla, and weeds such as Cyperus rotundus, Micania cordata, Urena lobata (L.), Biophytum reinwardtilii (Zucc.) Klotzch, and Oxalis L. sp. emerged from soil. This was followed by other herbaceous species such as Clidemia hirta and Dracaena thwaitesii, a few Pteridophytes and late successional species such as Aporusa lanceolata, Artocarpus spp., Todalia asiatica (L.) Lam. and Piper sylvestre, reflecting the sequence of species dominance in succession. Emergence of herbs and vines were more common in the forest edge compared to that of the forest interior (Figure 6).

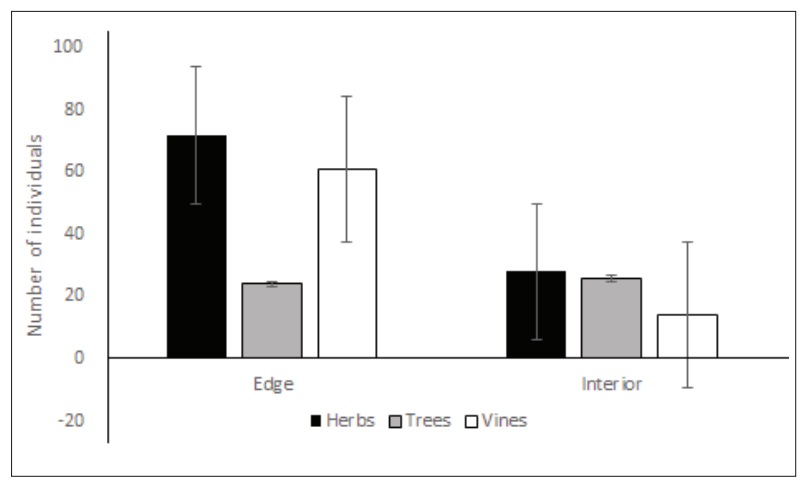

Figure 6: Abundance of herbs, trees and vines in soil seed bank of the edge and interior of the forest

The seed rain consisted of $47.83 \%$ epizoochory, $30.43 \%$ autochory and $21.74 \%$ anemochory seeds, respectively while seed bank analysis through the germination technique reported the highest percentage of seeds $(57.89 \%)$ from anemochory type, followed by $26.32 \%$ epizoochory and $15.79 \%$ autochory.

\section{Other implications of adjacent land-use practises on Kirigala forest}

It was observed that juvenile trees of the forest faced a comparatively greater threat than the seedlings and adult trees of some selected species such as Aporusa lanceolata and Maduca longifolia (L.) Macbride. Juveniles grown up to about $3-4 \mathrm{~m}$ height had been illegally removed by root ball technique for planting at various other sites (Figure 7). During such preparation, many neighbouring juveniles have been cut down for use as supporting material resulting in increased canopy openness and/or forest gaps of small scale.

Some areas of the forest were disturbed by people to create footpaths/ trails across the forest to reach the opposite sides (Figure 7). In some places, the forest was directly merged with cultivations without any border/ fence and this was noticed especially with the establishment of coffee plants beyond the border of the forest. In these areas none of the forest species were found to be naturally emerging from soil indicating an inhibition of germination and seedling growth, probably due to the phytotoxic properties of coffee (Peneva, 2007) or physical removal of other plants by the coffee growers. Results of seed bank and seed rain also showed encroachment of coffee plants into the forest. Therefore, growing coffee even on a small scale in adjacent areas may bring adverse effects in the long run by limiting the regeneration capability of the forest. 


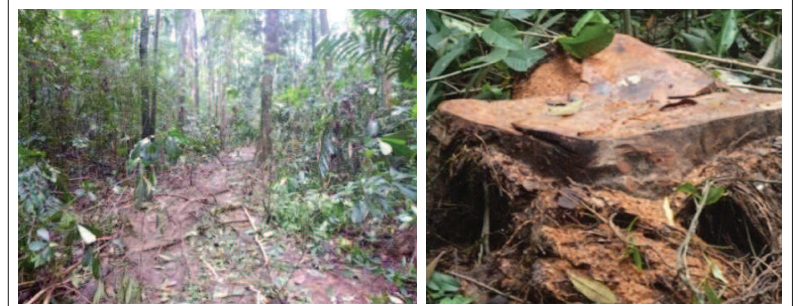

(A)

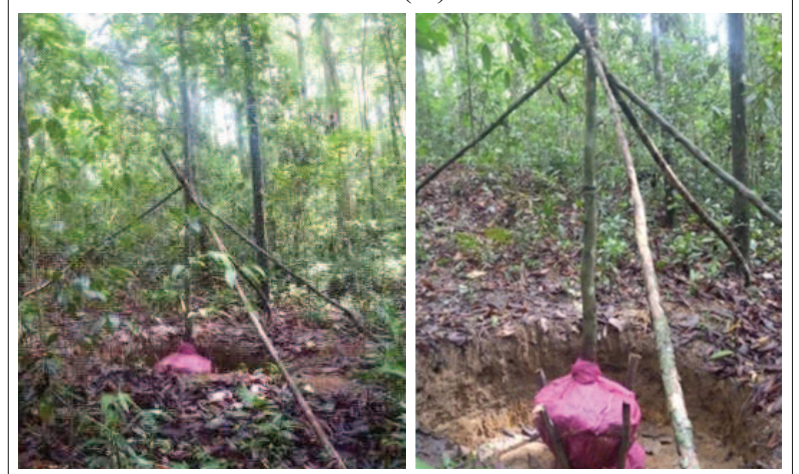

(B)

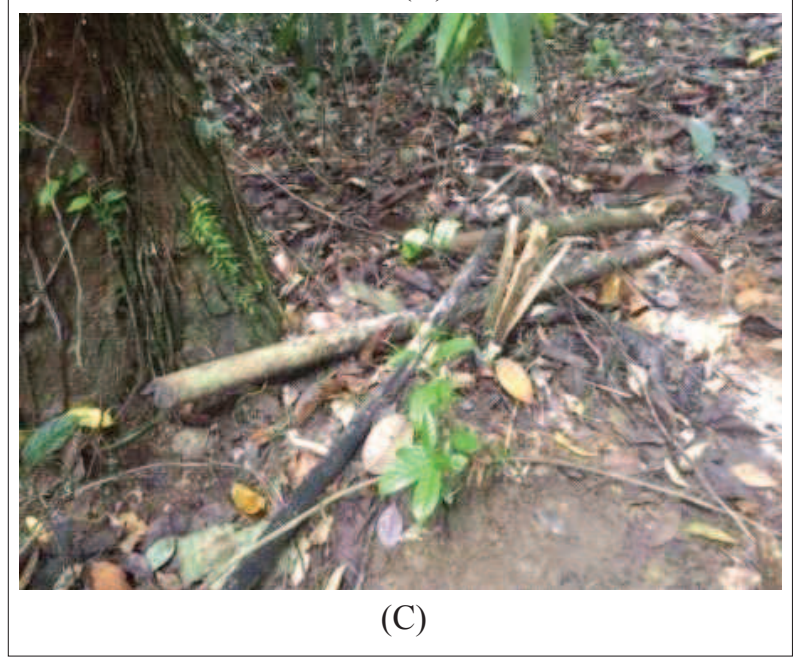

Figure 7: Human actions have degraded the forest - A) trails have been created; B) root ball process in progress; C) juveniles have been cut to be used as supporting stumps

\section{DISCUSSION}

The study clearly demonstrated the consequences of fragmentation and its subsequent influences on a suburban forest patch at Ingiriya. The impacts on forest vegetation, soil and micro-environment was evident along a disturbance gradient from the edge towards the interior. The forest periphery was more diversified than the interior as it had been the place of contact for fluxes of many organisms, materials and energy between the forest and surroundings as explained by the concept of edge effect. It also reflected the influences and impacts specific to neighbourhood land-uses (Colley et al., 2000; Cadenasso \& Pickett, 2001; Hamberg et al., 2009; Jayakumar \& Nair, 2013). The study was able to demonstrate the changes in species composition, floristic diversity and abundance of woody individuals up to $50 \mathrm{~m}$ into the interior of the forest.

It is of utmost importance to identify whether Kirigala could maintain its unique identity as a dipterocarp plantation or the 'Hora Kele' of Ingiriya. If so, the site should maintain a high abundance of adult trees and juveniles of D. zeylanicus. Based on the IVI values of the present study, the most dominant species at the edge and the interior was D. zeylanicus, but when the components of IVI (i.e. relative densities, frequencies and basal cover values) were considered it was evident that the IVI of D. zeylanicus was heavily supported by the higher basal area of adult $D$. zeylanicus trees. This was due to the occurrence of a few large individuals compared to that of the other forest species. Nevertheless, the age structure analysis indicated the presence of a viable stock of D. zeylanicus juveniles for its future survival. However, it is important to note that a declining trend of the woody stems of D. zeylanicus was reported at Kirigala over the years.

Attygalle (1998), and Attygalle and Singhakumara (1998) reported a decreasing density of adult trees of D. zeylanicus from $80 \%$ (Oudshoorn, 1961) to $52 \%$, and an increase of other species from 20 to $48 \%$ at Kirigala. As per their data, the estimation of seedlings (height $<1 \mathrm{~m}$ ), juveniles (height $>1 \mathrm{~m}, \mathrm{DBH}<10 \mathrm{~cm}$ ) and adult trees (height $>1 \mathrm{~m}, \mathrm{DBH}>10 \mathrm{~cm}$ ) of the forest had been 19,738, 3516 and 248, respectively. Six years later, an investigation of stand dynamics of $D$. zeylanicus by Weeraratne (2004) using the same plant categories estimated 11,109 seedlings, 2545 juveniles and 266 adult trees per hectare of the forest. The present study estimated 4033 seedlings, 833 juveniles and 917 adult trees per hectare of the forest when the same plant categories were considered. From this information it is evident that $i$ ) the establishment of $D$. zeylanicus seedlings have drastically decreased over the years, ii) some juveniles would have attained adult state while many had disappeared from the forest. It was also evident that with time the species richness had changed due to the immigration of plant propagules from surrounding environments as the plant species richness recorded in the present study indicated greater number of species than inventoried almost 16 years ago (82 total species belonging to 70 genera and 37 families) by Attygalle and Singhakumara (1998). The increase in the species richness including the endemic species could be due to the fact that Kirigala was left un-logged for some time. 
Hence, at present it is important to identify whether the Kirigala forest is to be managed as a dipterocarp plantation (Hora Kele) or as a good example of patches of forests that are truly undergoing natural regeneration towards developing into a typical lowland secondary rainforest. At present passive restoration of forests is gaining increasing popularity as a method of climate change adaptation and to enhance all kinds of (provisioning, supportive, supplying, regulatory and cultural) services of the ecosystems. Hence, we believe that more emphasis should be paid to protect Kirigala as patches of forests that would provide a variety of ecosystem services to the suburban areas of Colombo, rather than as a dipterocarp plantation that would provide a single species of timber.

Maintenance of species diversity is an important attribute of a forest community as it greatly contributes to the functioning of an ecosystem. It should be also noted that species diversity has the main role in altering the nutrient cycling pattern in environments (Kumar et al., 2010). According to Marchand and Houle (2006), a greater accumulation of soil organic matter can be observed in the forest interior. In the present study this was not observed probably due to the uneven discontinuous canopy cover, which could have altered the litter accumulation and deposition. Closed edges with dense vegetation can also increase litter accumulation so as to be similar to the forest interior. Soil fertility and $\mathrm{pH}$ had been usually higher at forest edges than that of the interior due to addition of nutrients carried by wind and anthropogenic activities (Hamberg et al., 2009). This could also result from the rapid turnover of litter from fast growing pioneer species including some invasive species. Murcia (1995) reported that the movement of fertilisers from adjacent croplands into the forest soil increase the nitrate and other nutrients at forest edges and decline towards the interior. Our results supported this view with regard to the potassium and nitrate contents of soil.

According to Colley et al. (2000), sealed edges (due to climbers and good canopy cover) are expected to impose less microclimatic changes. Our results have shown that humidity and soil moisture content in the forest interior is higher and uniform compared to low and fluctuated values at the edge. Closed edges (such as adjacent rubber plantation) also exhibited microclimatic features, which were similar to those of forest interior.

When the surrounding land-use type was a cropland, the forest edge contained only a few exotic representatives from the neighbourhood, and therefore did not change the diversity greatly compared to when the forest is surrounded by other land-uses. Roads and human settlements allow frequent movement of propagules of many exotic species and weeds into the forest (Borgmann \& Rodewald, 2005), and the edge of forest provides opportunities for establishment of many sun-loving weeds and/or invaders such as Mikania cordata and Clidemia hirta as reported here. As evident from this study, more strong and competitive species such as weedy and pioneer species with increased below and above ground seed availability satisfy the requirements and are recruited first (Laurance et al., 2000; Krebs, 2005). In comparison most of the forest species are disturbance intolerant and shade loving, hence in the seed bank of a disturbed forest, especially at the edge, abundance of these could be expected to be less. According to Iacona et al. (2010) and Coll et al. (2004), seedling recruitment in a particular location depends on the seed limitation, availability of safe sites for germination, competitive ability and resource acquisition. Under experimental conditions, the availability of safe micro-sites for germination could be limited whereas in natural environment litter, debris and soil provide safe environments for more seeds to germinate and for successful seedling establishment, especially for the establishment of native woody species of the forest.

It is also important to note the encroachment pressure of the woody forest invader, Alstonia macrophylla on the forest. The presence of $A$. macrophylla propagules in large quantities in the seed rain and seed bank of the forest indicated that $A$. macrophylla is a potential threat to the Kirigala rainforest in the near future. If selective removal of juveniles of native species continue, the opportunities of establishment of light demanding A. macrophylla within the forest may increase and thus urgent action should be taken to prohibit this activity and minimise public access into the forest.

Across the Kirigala forest, trampling of vegetation besides the trails or footpaths had damaged the forest understory vegetation and caused damage to forest undergrowth and seedling establishment. This is obvious when forest fragments are bordered by the road network. The presence of seedlings of D. zeylanicus, G. vaginans and $A$. lanceolata in copious amounts in the undergrowth of the forest periphery may show that they could resist trampling. Different plant species have different abilities to withstand trampling and in many instances the most successful ones that could tolerate trampling have been weeds and alien invaders (Hamberg et al., 2010). It is also worthwhile to continue observations on growing coffee even on a small scale in adjacent areas of the forest as this may bring adverse effects in the long run by limiting the regeneration capability of the native 
forest species. The removal of saplings and trees from the forest directly change the structure, composition and the succession and regeneration processes of the forest. Thus, the forest seems to be losing the ability to maintain its profile if these activities are allowed to continue in the coming years.

The floristic richness including the 25 endemic flora (nearly $25 \%$ endemism) reported from the observational sites provides a value addition to Kirigala forest. On the other hand, the spread of weedy and invasive alien species, various direct and indirect human impacts reflected from the neighbourhood land-use practices, canopy gaps created due to illicit felling of trees and selective removal of woody saplings heavily devalue the forest ecosystem. As these impacts can be easily recognised and estimated through visual means, there is a high probability that dynamics of the forest periphery will be often projected over the entire forest during the dilemma between conservation and development. Ecological knowledge is critical to understand the value and functions of an ecosystem and such data are essential to be considered during decision making process when drawing up management plans for forest resources.

\section{CONCLUSION}

Degradation of Kirigala forest due to anthropogenic disturbances and edge effect is continuing at an alarming rate at present affecting its structure, function, microclimate and natural regeneration. Removal of woody juveniles, clearing for footpaths and trails, encroachment of croplands and spread of invasive alien species have significantly contributed to degrade it further over the recent years. The abundance of $D$. zeylanicus also reflect a declining trend and the regeneration of native species has not been favoured. These evidences point to whether Kirigala forest will be able to maintain its identity if attention is not paid on its management and restoration. Urgent action of management is vital to ensure its future existence.

\section{Acknowledgement}

A special appreciation is due to the Forest Department for permission, University of Colombo for financial assistance and infra-structure facilities provided for investigations.

\section{REFERENCES}

1. Attygalle P.R. (1998). Ecological assessment and management aspects of Dipterocarpus zeylanicus plantation at Kirigala, Ingiriya. MSc thesis, University of Sri Jayewardenepura, Sri Lanka.

2. Attygalle P.R. \& Singhakumara P. (1998). The ecology of Dipterocarpus zeylanicus plantation at Ingiriya, Proceedings of the Fourth Annual Forestry and Environment Symposium, Department of Forestry and Environment Science, University of Sri Jayewardenepura, 3-4 December, Beruwala, Sri Lanka, p. 42.

3. Borgmann K.L. \& Rodewald A.D. (2005). Forest restoration in urbanizing landscapes: interaction between land uses and exotic shrubs. Restoration Ecology 13: 334 - 340. DOI: http://dx.doi.org/10.1111/j.1526-100X.2005.00042.x

4. Broadbent E.N., Asnera G.P., Keller M., Knapp D.E., Oliveira P.J. \& Silva J.N. (2008). Forest fragmentation and edge effects from deforestation and selective logging in the Brazilian Amazon. Biological Conservation 141: 1745 1757.

DOI: http://dx.doi.org/10.1016/j.biocon.2008.04.024

5. Cadenasso M.L. \& Pickett S.T.A. (2001). Effect of edge structure on the flux of species into forest interior. Conservation Ecology 15: 91 - 97.

DOI: http://dx.doi.org/10.1111/j.1523-1739.2001.99309.x

6. Coll L., Balandier P., Catherine P., Bernard P. \& Thomas C. (2004). Competition for water between beech seedlings and surrounding vegetation in different light and vegetation composition conditions. Annals of Forest Science 60: $593-600$. DOI: http://dx.doi.org/10.1051/forest:2003051

7. Colley D.R.J., Payne G.W. \& Elswijk M. (2000). Microclimatic gradient across a forest edge. New Zealand Journal of Ecology 24: 111 - 121.

8. Collinge S.K. (1996). Ecological consequences of habitat fragmentation: implications for landscape architecture and planning. Landscape and Urban Planning 36: 59 - 77. DOI: http://dx.doi.org/10.1016/S0169-2046(96)00341-6

9. Dassanayake M.D., Clayton W.D. \& Fosberg F.R. (1995 2006). A Revised Handbook to the Flora of Ceylon, volume 1 - 9. Oxford \& IBH Publishing Co. Pvt. Ltd., New Delhi, India.

10. De Vlas J.J. (2008). Illustrated Field Guide to the Flowers of Sri Lanka. Mark Book Sellers and Distributors Pvt. Ltd., Kandy, Sri Lanka.

11. Dixo M., Metzger J.P., Morgante J.S. \& Zamudio K.R. (2009). Habitat fragmentation reduces genetic diversity and connectivity among toad populations in the Brazilian Atlantic coastal forest. Biological Conservation 142: 1560 -1569 .

DOI: http://dx.doi.org/10.1016/j.biocon.2008.11.016

12. Echeverria C., Coomes D., Salas J., Rey-Benayas M.J., Lara A. \& Newton A. (2006). Rapid deforestation and fragmentation of Chilean temperate forests. Biological Conservation 130: 481 - 494.

DOI: http://dx.doi.org/10.1016/j.biocon.2006.01.017

13. Fruit Crop Research and Development Center (FCRDC) (2013). Annual Report. Fruit Crop Research and Development Center, Department of Agriculture, Horana.

14. Ghimire R., Dahal S.C., Sah K.R., Shrestha A.K., Adhikari C. \& Lauren J.G. (2007). Equation for predicting soil 
organic carbon using loss on ignition for chitwan valley soil. IAAS Research Advances 1: 229 - 232.

15. Godefroid S. \& Koedam N. (2003). Distribution pattern of the flora in a peri-urban forest: an effect of the city-forest ecotone. Landscape and Urban Planning 65: 169 - 185. DOI: http://dx.doi.org/10.1016/S0169-2046(03)00013-6

16. Hamberg L., Lehvavirta S. \& Kotze D.J. (2009). Forest edge structure as a shaping factor of understory vegetation in urban forests in Finland. Forest Ecology and Management 257: $712-722$.

DOI: http://dx.doi.org/10.1016/j.foreco.2008.10.003

17. Harper K.A., Macdonald S.E., Burton P.J., Chen J. \& Brosofske K.D. (2005). Edge influence on forest structure and composition in fragmented landscape. Conservation Biology 19: 768 - 782.

DOI: http://dx.doi.org/10.1111/j.1523-1739.2005.00045.x

18. Iacona G.D., Katherine K. \& Bruna E.M. (2010). Effects of resource availability on seedling recruitment in a firemaintained savanna. Oecologia 163: $171-180$. DOI: http://dx.doi.org/10.1007/s00442-009-1502-y

19. IUCN-MoESE (2012). The 2012 Red List of Threatened Fauna and Flora of Sri Lanka. IUCN Sri Lanka \& Ministry of Environment and Sustainable Energy, Sri Lanka.

20. Jayakumar R. \& Nair N. (2013). Species diversity and tree regeneration patterns in tropical forests of the Western Ghats, India. ISRN Ecology, Article ID 890862.

DOI: http://dx.doi.org/10.1155/2013/890862

21. Krebs C.J. (2005). Ecology. The Experimental Analysis of Distribution and Abundances. Pearson Publication, San Francisco, USA.

22. Kumar N., Kumar R., Kumar R.N. \& Sajish P.R. (2010). Tree species diversity and soil nutrient status in three sites of tropical dry deciduous forest of western India. Tropical Ecology 51: 273 - 279.

23. Laurance W.F., Delamonica P., Laurance S.G., Vasconcelos H.L. \& Lovejoy T.E. (2000). Rainforests fragmentation kills big trees. Nature 404: 836.

DOI: http://dx.doi.org/10.1038/35009032

24. Lin L. \& Cao M. (2009). Edge effect on soil seed banks and understory in subtropical and tropical forests in Yuannan, SW China. Forest Ecology and Management 257: 1344 1352.

DOI: http://dx.doi.org/10.1016/j.foreco.2008.12.004

25. Marchand P. \& Houle G. (2005). Spatial patterns of plant species richness along a forest edge: What are their determinants? Forest Ecology and Management 223: 113 -124 .
DOI: http://dx.doi.org/10.1016/j.foreco.2005.10.064

26. Ministry of Environment and Natural Resources (MoENR) (2009). Fourth National Report to the Convention on Biological Diversity. Ministry of Environment and Natural Resources, Battaramulla.

27. Ministry of Forestry and Environment (MoFE) (1999). Biodiversity Conservation in Sri Lanka: a Framework for Action. Ministry of Forestry and Environment, Sri Lanka.

28. Murcia C. (1995). Edge effects in fragmented forests: implication for conservation Trends in Ecology and Evolution 10: 58 - 62 .

29. Nagendra H. (2002). Opposite trends in response for the Shannon and Simpson indices of landscape diversity. Applied Geography 22: 175 - 186.

30. Olsen S.R., Cole C.V. \& Watanabe F.S. (1954). Estimation of available phosphorous in soil by extraction with sodium bicarbonate. USDA Circular 939. United States Department of Agriculture, Washington DC, USA.

31. Oudshoorn W. (1961). A Forest Inventory of the Indikada, Kirigala and Kurana Madakada Proposed Reserves of Ceylon. Forest Department, Sri Lanka.

32. Peneva A. (2007). Allelopathic effect of seed extracts and powder of coffee (Coffea arabica L.) on common cocklebur (Xanthium strumarium L.). Bulgarian Journal of Agricultural Science 13: 205 - 211.

33. Pokhriyal P., Uniyal P., Chauhan D.S. \& Todaria N.P. (2010). Regeneration status of tree species in forest of Phakot and PathriRao watersheds in Garhwal Himalaya. Current Science 98: 171 - 175.

34. Porensky L.M. \& Young T.P. (2013). Edge effect interactions in fragmented and patchy landscape. Conservation Biology 27: $509-519$.

35. Tawatao N., Harper N.E., Mohamed M., Khen C.V., Searle J.B. \& Hill J.K. (2011). Impacts of forest fragmentation on the genetic diversity and population structure of Pachycondyla obscurans in Sabah, Malaysian Borneo. Asian Myrmecology 4: 59 - 68. DOI: http://dx.doi.org/10.1111/cobi.12042

36. Senaratna L.K. (2001). A Checklist of the Flowering Plants of Sri Lanka. National Science Foundation, 47/5, Maitland Place, Colombo 07, Sri Lanka.

37. Stern R.D., Coe R., Allen E.F. \& Dale I.C. (eds). (2004). Good Statistical Practical for Natural Resources Research. CABI Publishing, Wallingford, UK.

38. Weeraratne J.H. (2004). Stand dynamics of Dipterocarpus zeylanicus Thw. plantation at Kirigala Ingiriya. MSc thesis, University of Sri Jayewardenepura, Sri Lanka. 


\section{APPENDIX}

Plant species distribution at edge and interior of the forest with regard to neighbourhood land use types.

[En = endemic; In = invasive; H- herb; T - tree; S - shrub; C - climber; V - vine. * indicate the presence of species at forest edge (E); interior (I); relative frequency $(\mathrm{RF})$; relative basal area $(\mathrm{RBA})$; relative density $(\mathrm{RD})$; important value index (IVI)]

\begin{tabular}{|c|c|c|c|c|c|c|c|c|c|}
\hline Family & Species & 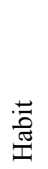 & 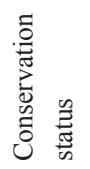 & $\mathrm{E}$ & I & $\mathrm{RF}$ & RBA & $\mathrm{RD}$ & IVI \\
\hline Anacardiaceae & Mangifera indica $\mathrm{L}$. & $\mathrm{T}$ & - & $*$ & & 0.46 & 0.02 & 0.17 & 0.65 \\
\hline Anacardiaceae & Mangifera zeylanica (Blume) Hook. f. & $\mathrm{T}$ & En & & * & & & & \\
\hline Anacardiaceae & Semecarpus marginata Thw. & $\mathrm{T}$ & En & & $*$ & 0.93 & 0.01 & 0.34 & 1.28 \\
\hline Anacardiaceae & Semecarpus nigro-viridis Thw. & $\mathrm{T}$ & En & * & & 1.39 & 0.05 & 0.52 & 1.95 \\
\hline Annonaceae & Artabotrys zeylanicus Hook. F. \&Thoms. & $\mathrm{C}$ & - & $*$ & & & & & \\
\hline Apocyanaceae & Alstonia macrophylla Wall. ex G. Don & $\mathrm{T}$ & In & $*$ & * & 2.31 & 4.12 & 1.03 & 7.46 \\
\hline Apocyanaceae & Alstonia scholaris (L.) R. Br. & $\mathrm{T}$ & - & $*$ & * & 0.46 & 0.29 & 0.17 & 0.93 \\
\hline Apocyanaceae & Pagiantha dichotoma (Roxb.) Markgraf & $\mathrm{T}$ & - & * & * & 1.39 & 0.25 & 0.69 & 2.33 \\
\hline Apocyanaceae & Petchia ceylanica (Wight) Livera & $\mathrm{S}$ & En & $*$ & & & & & \\
\hline Araceae & Alocasia macrorrhizos (L.) G. Don & $\mathrm{H}$ & - & * & & & & & \\
\hline Araceae & Pothos scandens L. & $\mathrm{C}$ & - & $*$ & * & & & & \\
\hline Araceae & Syngonium angustatum Schott & $\mathrm{C}$ & - & $*$ & & & & & \\
\hline Areaceae & Areca catechu $\mathrm{L}$. & $\mathrm{T}$ & - & $*$ & & 1.39 & 0.19 & 0.52 & 2.10 \\
\hline Areaceae & Caryota urens $\mathrm{L}$. & $\mathrm{T}$ & - & $*$ & * & 1.39 & 0.04 & 0.52 & 1.94 \\
\hline Aristolochiaceae & Thottea siliquosa (Lam.) Ding Hou & $\mathrm{S}$ & - & $*$ & & & & & \\
\hline Asteraceae & Wedelia biflora (L.) DC. & $\mathrm{H}$ & - & $*$ & & & & & \\
\hline Asteraceae & Mikania cordata (Burm.) Robinson & $\mathrm{V}$ & In & $*$ & & & & & \\
\hline Bignoniaceae & Stereospermum colais (Dillwyn) Mabb & $\mathrm{T}$ & - & $*$ & & 0.46 & 0.01 & 0.17 & 0.64 \\
\hline Burseraceae & Canarium zeylanicum (Retz.) Blume & $\mathrm{T}$ & En & & * & 0.93 & 0.05 & 0.52 & 1.49 \\
\hline Celastraceae & Bhesa ceylanica (Arn. ex Thw.) Ding Hou & $\mathrm{T}$ & En & $*$ & * & 2.78 & 0.29 & 1.20 & 4.27 \\
\hline Clusiaceae & Calophyllum inophyllum $\mathrm{L}$. & $\mathrm{T}$ & - & & & & & & \\
\hline Clusiaceae & Garcinia xanthochymus Hook. f. & $\mathrm{T}$ & - & & * & 10.65 & 1.41 & 25.60 & 37.66 \\
\hline Dilleniaceae & Dillenia retusa Thunb. & $\mathrm{T}$ & - & $*$ & * & 1.85 & 0.11 & 0.86 & 2.82 \\
\hline Dilleniaceae & Dillenia suffruticosa (Griffiith) Martelli & $\mathrm{T}$ & In & $*$ & & 0.46 & 0.09 & 0.17 & 0.72 \\
\hline Dilleniaceae & Schumacheria castaneifolia Vahl & $\mathrm{T}$ & En & & * & 0.93 & 0.13 & 0.34 & 1.40 \\
\hline Dilleniaceae & Tetracera sarmentosa (L.) Vahl & $\mathrm{C}$ & En & $*$ & & & & & \\
\hline Dioscoreaceae & Dioscorea bulbifera L. & $\mathrm{V}$ & - & & & & & & \\
\hline Dipterocarpaceae & Dipterocarpus zeylanicus Thw. & $\mathrm{T}$ & En & $*$ & * & 12.50 & 62.73 & 15.29 & 90.52 \\
\hline Dracaenaceae & Dracaena thwaitesii Regel & $\mathrm{H}$ & - & $*$ & * & & & & \\
\hline Ebenaceae & Diospyros insignis Thw. & $\mathrm{T}$ & - & & * & 0.46 & 0.02 & 0.17 & 0.66 \\
\hline Elaeocarpaceae & Elaeocarpus serratus L. & $\mathrm{T}$ & - & $*$ & * & 0.93 & 0.03 & 0.34 & 1.30 \\
\hline Elaeocarpaceae & Elaeocarpus subvillosus Arn. & $\mathrm{T}$ & En & $*$ & * & 0.46 & 0.02 & 0.17 & 0.66 \\
\hline Euphorbiaceae & Aporusa lanceolata (Tul.) Thw. & $\mathrm{T}$ & En & $*$ & * & 9.72 & 2.16 & 9.79 & 21.68 \\
\hline Euphorbiaceae & Bridelia moonii Thw. & $\mathrm{T}$ & En & $*$ & * & 3.24 & 7.15 & 1.37 & 11.77 \\
\hline Euphorbiaceae & Bridelia retusa (L.) A. Juss. & $\mathrm{T}$ & - & & & 0.46 & 0.21 & 0.17 & 0.84 \\
\hline Euphorbiaceae & Chaetocarpus coriaceus Thw. & $\mathrm{T}$ & En & $*$ & & 0.93 & 0.27 & 0.34 & 1.54 \\
\hline Euphorbiaceae & Fahrenheitia minor (Thw.) Ary Shaw & $\mathrm{T}$ & En & $*$ & * & 6.48 & 1.54 & 8.59 & 16.62 \\
\hline Euphorbiaceae & Hevea brasiliensis (A. Juss.) Muell. Arg. & $\mathrm{T}$ & - & $*$ & & 0.93 & 0.13 & 0.52 & 1.57 \\
\hline
\end{tabular}




\begin{tabular}{|c|c|c|c|c|c|c|c|c|c|}
\hline Family & Species & 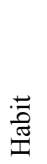 & 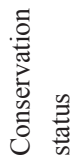 & $\mathrm{E}$ & $\mathrm{I}$ & RF & RBA & $\mathrm{RD}$ & IVI \\
\hline Euphorbiaceae & Macaranga peltata (Roxb.) Muell. Arg. & $\mathrm{T}$ & - & * & & & & & \\
\hline Euphorbiaceae & Mallotus rhamnifolis (Willd.) Muell. Arg. & $\mathrm{T}$ & - & * & $*$ & 2.31 & 0.34 & 7.22 & 9.87 \\
\hline Euphorbiaceae & Mallotus tetracoccus (Roxb.) Kurz & $\mathrm{T}$ & - & $*$ & & & & & \\
\hline Euphorbiaceae & Sauropus androgynus (L.) Merr. & $\mathrm{S}$ & - & & & 0.46 & 0.01 & 0.17 & 0.64 \\
\hline Euphorbiaceae & Suregada lanceolata (Willd.) Kuntze & $\mathrm{T}$ & - & * & & 0.46 & 0.00 & 0.17 & 0.64 \\
\hline Lauraceae & Cinnamomum verum J. Presl & $\mathrm{T}$ & - & & & & & & \\
\hline Lauraceae & Litsea longifolia (Nees) Trimen & $\mathrm{T}$ & En & * & & 1.39 & 0.80 & 0.86 & 3.05 \\
\hline Lauraceae & Persea americana Miller & $\mathrm{T}$ & - & $*$ & & & & & \\
\hline Marattiaceae & Angiopteris evecta (Forst.) Hoffin & $\mathrm{H}$ & - & $*$ & & & & & \\
\hline Melastomataceae & Clidemia hirta(L.) D. Don & $\mathrm{S}$ & In & $*$ & & & & & \\
\hline Melastomataceae & Osbeckia octandra (L.) DC. & $\mathrm{S}$ & En & * & & & & & \\
\hline Meliaceae & Swietenia macrophylla King & $\mathrm{T}$ & In & $*$ & & 0.93 & 0.11 & 0.34 & 1.38 \\
\hline Moraceae & Artocarpu incisus L. f. & $\mathrm{T}$ & - & $*$ & & 1.39 & 0.07 & 0.69 & 2.15 \\
\hline Moraceae & Artocarpus heterophyllus Lam. & $\mathrm{T}$ & - & $*$ & $*$ & 1.39 & 5.51 & 0.86 & 7.76 \\
\hline Moraceae & Artocarpus nobilis Thw. & $\mathrm{T}$ & En & $*$ & $*$ & 1.85 & 1.76 & 1.03 & 4.64 \\
\hline Moraceae & Ficus callosa Willd. & $\mathrm{T}$ & - & & & 0.93 & 0.35 & 0.34 & 1.62 \\
\hline Moraceae & Ficus nervosa Heyne ex Roth & $\mathrm{T}$ & - & & & 0.46 & 0.00 & 0.17 & 0.64 \\
\hline Moraceae & Ficus diversiformis Miq. & $\mathrm{C}$ & En & & $*$ & & & & \\
\hline Moraceae & Ficus hispida L. f. & $\mathrm{T}$ & - & $*$ & & 0.46 & 0.04 & 0.52 & 1.02 \\
\hline Myristicaceae & Horsfieldia iryaghedhi (Gaertn.) Warb. & $\mathrm{T}$ & En & $*$ & $*$ & 4.63 & 4.35 & 3.44 & 12.41 \\
\hline Myristicaceae & Myristica dactyloides Gaertn. & $\mathrm{T}$ & - & $*$ & $*$ & 4.17 & 1.43 & 3.09 & 8.69 \\
\hline Myrtaceae & Syzygium caryophyllatum (L.) Alston & $\mathrm{T}$ & - & $*$ & & 0.46 & 0.01 & 0.17 & 0.64 \\
\hline Myrtaceae & Syzygium neesianum Arn. & $\mathrm{T}$ & - & & & 0.46 & 0.05 & 0.17 & 0.69 \\
\hline Oxalidaceae & Biophytum reinwardtii (Zucc.) Klotzsch & $\mathrm{H}$ & - & $*$ & & & & & \\
\hline Piperaceae & Peperomia pellucida (L.) Kunth & $\mathrm{H}$ & - & $*$ & & & & & \\
\hline Piperaceae & Piper sylvestre Lam. & $\mathrm{C}$ & - & $*$ & $*$ & & & & \\
\hline Poaceae & Ochlandra stridula Moon ex Thw. & $\mathrm{S}$ & En & $*$ & $*$ & & & & \\
\hline Poaceae & Alloteropsis cimicina (L.) Stapf & $\mathrm{H}$ & - & $*$ & & & & & \\
\hline Poaceae & Axonopus affinis Chase & $\mathrm{H}$ & - & $*$ & & & & & \\
\hline Polygonaceae & Xanthophyllum zeylanicum Meijden & $\mathrm{S}$ & En & $*$ & $*$ & 1.85 & 0.08 & 1.20 & 3.13 \\
\hline Pteridaceae & Adinatum caudatum L. & $\mathrm{H}$ & - & & $*$ & & & & \\
\hline Pteridaceae & Adiantum trapeziforme L. & $\mathrm{H}$ & - & $*$ & & & & & \\
\hline Pteridaceae & Adiantum latifolium Lam. & $\mathrm{H}$ & - & $*$ & $*$ & & & & \\
\hline Rhamnaceae & Ziziphus mauritiana Lam. & $\mathrm{S}$ & - & $*$ & & & & & \\
\hline Rhamnaceae & Ziziphus rugosa Lam. & $\mathrm{S}$ & - & $*$ & $*$ & 0.93 & 0.16 & 0.34 & 1.43 \\
\hline Rhizophoraceae & $\begin{array}{l}\text { Anisophyllea cinnamomoides (Gardner \& } \\
\text { Chapion) Alston }\end{array}$ & $\mathrm{S}$ & En & $*$ & $*$ & 0.93 & 0.01 & 0.34 & 1.28 \\
\hline Rubiaceae & Coffea arabica $\mathrm{L}$. & $\mathrm{T}$ & - & $*$ & * & 2.78 & 0.23 & 5.50 & 8.50 \\
\hline Rubiaceae & Gaertnera vaginans (DC.) Merr. & $\mathrm{T}$ & - & $*$ & $*$ & 10.65 & 1.41 & 25.60 & 37.66 \\
\hline Rubiaceae & Ixora coccinea $\mathrm{L}$. & $\mathrm{S}$ & - & & & & & & \\
\hline Rubiaceae & Lasianthus oliganthus (Thw.) Thw. & $\mathrm{T}$ & En & $*$ & & 0.46 & 0.01 & 0.17 & 0.64 \\
\hline Rutaceae & Melicope lunu-ankenda (Gaertn.) T. Hartley & $\mathrm{T}$ & - & & $*$ & 0.93 & 1.81 & 0.34 & 3.08 \\
\hline Rutaceae & Toddalia asiatica (L.) Lam. & $\mathrm{C}$ & - & $*$ & & & & & \\
\hline
\end{tabular}




\begin{tabular}{|c|c|c|c|c|c|c|c|c|c|}
\hline Family & Species & $\begin{array}{l}\text { : } \\
\text { 营 }\end{array}$ & 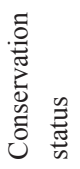 & $\mathrm{E}$ & I & $\mathrm{RF}$ & RBA & $\mathrm{RD}$ & IVI \\
\hline Sapindaceae & Nephelium lappaceum $\mathrm{L}$. & $\mathrm{T}$ & - & & & 0.93 & 0.01 & 0.52 & 1.46 \\
\hline Sapotaceae & Chrysophyllum roxburghii $\mathrm{G}$. Don & $\mathrm{T}$ & - & * & & 0.46 & 0.08 & 0.17 & 0.72 \\
\hline Sapotaceae & Isonandra lanceolata Wight & $\mathrm{S}$ & - & * & & 0.93 & 0.12 & 0.52 & 1.57 \\
\hline Sapotaceae & Madhuca longifolia (L.) Macbride & $\mathrm{T}$ & - & * & & 0.93 & 0.05 & 0.34 & 1.31 \\
\hline Symplocaceae & Symplocos cochinchinensis (Lour.) S. Moore & $\mathrm{T}$ & - & * & $*$ & 1.39 & 0.11 & 0.86 & 2.36 \\
\hline Thelipteridaceae & $\begin{array}{l}\text { Christella dentata (Forssk.) Brownsay \& } \\
\text { Jermy. Brit. Fern. Gaz. }\end{array}$ & $\mathrm{H}$ & - & * & & & & & \\
\hline Thelipteridaceae & Christella hispidula (Decne.) Holtt. & $\mathrm{H}$ & - & * & * & & & & \\
\hline Thymelaceae & Gyrinops walla Gaertn. & $\mathrm{T}$ & - & & $*$ & 0.46 & 0.03 & 0.34 & 0.83 \\
\hline Verbenaceae & Clerodendrum phlomidis L. & $\mathrm{T}$ & - & * & & 0.46 & 0.01 & 0.17 & 0.64 \\
\hline Vitaceae & Cissus trilobata Lam. & $\mathrm{H}$ & - & * & $*$ & & & & \\
\hline Zingiberaceae & Zingiber cylindricum Thw. & $\mathrm{H}$ & - & & $*$ & & & & \\
\hline
\end{tabular}

